\title{
SEKOLAH MENENGAH KEJURUAN TEKNIK KOMPUTER DAN INFORMATIKA DI KUBU RAYA
}

\author{
Kharisma Adam $^{1}$, Zairin Zain ${ }^{2}$, Valentinus Pebriano ${ }^{3}$ \\ ${ }^{1}$ Mahasiswa, Program Studi Arsitektur, Fakultas Teknik, Universitas Tanjungpura \\ Kharismadm532@student.untan.ac.id \\ ${ }^{2}$ Program Studi Arsitektur, Fakultas Teknik, Universitas Tanjungpura \\ ${ }^{3}$ Program Studi Arsitektur, Fakultas Teknik, Universitas Tanjungpura
}

Naskah diajukan pada: 15 Februari 2021

Naskah revisi akhir diterima pada: 17 Februari 2021

\begin{abstract}
Abstrak
Perkembangan teknologi yang terus berevolusi membawa perubahan dalam berbagai kegiatan seperti proses industri yang sangat bergantung dengan komputer dan teknologi robot untuk efisiensi dan peningkatan produksi industri. Dari perkembangan industri tersebut diperlukan SDM berkompeten yang dapat bersaing pada dunia industri. Salah satu cara untuk meningkatkan SDM bidang teknologi adalah membangun Sekolah Menengah Kejuruan Teknik Komputer dan Informatika. Diperlukan pembenahan dan penambahan fasilitas untuk mendukung pendidikan di Kabupaten Kubu Raya. Tahapan perancangan Sekolah Menengah Kejuruan Teknik Komputer dan Informatika di Kabupaten Kubu Raya dimulai dari tahap persiapan, tahap analisis, tahap sintesis dan tahap rancangan. Penerapan pemahaman arsitektur tropis dengan pertimbangan prinsip kenyamanan spasial pada bangunan terkait aspek ukuran tubuh pengguna bangunan, aspek ruang gerak manusia berdasarkan aktivitas manusia di dalamnya, kenyamanan audial, kenyamanan visual dan kenyamanan termal pada bangunan. Penerapan energi terbarukan seperti pembangkit listrik tenaga surya yang diaplikasikan pada fasad bangunan untuk memenuhi sumber listrik dan penghambat sinar matahari masuk ke dalam ruangan. Selain itu penerapan material dinding dan roaster bata laterit untuk menyerap kelembaban udara menyesuaikan geografis Kabupaten Kubu Raya yang merupakan daerah tropis. Bentukan bangunan dengan filosofi gubahan bentuk dan analogi ruangan dari Printed Circuit Board memberikan makna akses ruangan yang terhubung antara satu sama lain.
\end{abstract}

Kata-kata Kunci: Sekolah Menengah Kejuruan, Jurusan Teknik Komputer dan Informatika, Pendekatan Arsitektur Tropis

\begin{abstract}
Technological developments that continue to evolve changes in various activities such as industries that rely heavily on computers and robot technology to increase industrial production. From this industrial development, it requires competent human resources who can compete in the industrial world. One way to improve human resources in the field of technology is to build a Computer Engineering and Informatics Vocational High School. Improvement and additional facilities are needed to support education in Kubu Raya Regency. The design stages of the Computer and Informatics Engineering Vocational High School in Kubu Raya Regency start from the preparation stage, the analysis stage, the synthesis stage and the design stage. Application of understanding tropical architecture with consideration of the principle of spatial comfort in buildings related to aspects of the body size of the building user, aspects of human space based on human activities in it, audio comfort, visual comfort, and thermal comfort in buildings. The application of renewable energy, such as solar power generation, is applied to building facades to provide electricity sources and block light from entering the room. In addition, the application of laterite brick material and roaster for air humidity adjusts the geographical area of Kubu Raya Regency which is a tropical area. The formation of buildings with a philosophical composition of shapes and room analogies from the Printed Circuit Board gives the meaning of access to rooms that are connected to one another.
\end{abstract}

Keywords: Vocational High School, Department of Computer and Informatics Engineering, Tropical Architectural Approaches 


\section{Pendahuluan}

Dalam menghadapi perkembangan teknologi seiring dengan revolusi industri keempat, semua kegiatan produksi dilakukan dengan menerapkan konsep otomatisasi yaitu konsep melakukan kegiatan produksi dengan menggunakan tenaga mesin. Kegiatan ini sangat berpengaruh dalam efisiensi waktu dan peningkatan produktifitas kegiatan produksi. Pada revolusi industri keempat ini diperlukan sumber daya manusia yang kompeten untuk bersaing di dunia industri teknologi. Indonesia membutuhkan sarana dan prasarana yang baik untuk menghasilkan sumber daya manusia terampil, sehingga dapat menyesuikan kebutuhan pasar kerja pada zaman yang sangat dinamis.

Banyak program pemerintah dalam meningkatkan kemajuan bidang TIK, seperti pengembangan industri teknologi informasi dan gerakan 1.000 start up yang jadi fokus Indonesia hingga tahun 2035. Berbagai program tersebut memerlukan banyak tenaga ahli bidang TIK. Indonesia tengah mengalami kekurangan tenaga programmer, sehingga dibutuhkan pendidikan vokasi untuk menciptakan lulusan yang lebih kompetitif dan siap dalam dunia industri yang sangat bergantung pada teknologi dalam proses produksinya.

Berdasarkan Undang-Undang No. 20 Tahun 2003, pasal 18 ayat 3, Sekolah Menengah Kejuruan (SMK) merupakan salah satu bentuk satuan pendidikan formal yang menyelenggarakan pendidikan kejuruan sebagai lanjutan dari Sekolah Menengah Pertama (SMP), Madrasah Tsanawiyah (MTs), atau bentuk lain yang sederajat. Sekolah menengah kejuruan dimaksudkan untuk mengembangkan kemampuan peserta didik siswa. Keterampilan yang diajarkan di jenjang ini adalah hasil belajar siswa selama kegiatan di sekolah dan praktek langsung pada industri yang bersangkutan dengan jurusan yang diambil.

Kabupaten Kubu Raya masih minim fasilitas dan banyak kerusakan sarana dan prasarana sekolah sehingga diperlukan pembenahan berbagai fasilitas untuk menghasilkan SDM yang berkualitas di Kabupaten Kubu Raya. Salah satu fasilitas pendukung kelancaran proses belajar dan mengajar adalah ruang teori maupun praktik yang nantinya akan dijadikan sebagai tempat belajar dan mengajar.

Berdasarkan data BPS Kabupaten Kubu Raya (2018), disebutkan jumlah ruang kelas untuk sekolah menengah kejuruan masih terbilang tidak mencukupi untuk menampung penduduk usia jenjang sekolah menengah kejuruan di Kabupaten Kubu Raya. Ruang kelas yang tersedia untuk sekolah negeri berjumlah 420 ruang kelas, sedangkan kelas sekolah swasta berjumlah 301 kelas. Jumlah total kelas jenjang SLTA di Kabupaten Kubu Raya adalah 721 kelas. Jumlah total penduduk laki-laki di Kabupaten Kubu Raya pada jenjang umur 15 hingga 19 tahun adalah 27.730 jiwa dan jumlah penduduk perempuan jenjang umur 15 hingga 19 tahun di Kabupaten Kubu Raya adalah 26.268 jiwa. Total keseluruhan penduduk laki-laki dan perempuan pada jenjang umur 15 hingga 19 tahun di Kabupaten Kubu Raya adalah 53.998 jiwa. Jumlah ini akan terus bertambah seiring perkembangan zaman.

Data rombongan belajar di Kabupaten Kubu Raya untuk tingkat SMP sebanyak 523 rombongan belajar, tingkat SMA 278 rombongan belajar, dan tingkat SMK adalah 181 rombongan belajar. Jumlah total rombongan belajar di Kabupaten Kubu Raya adalah sebanyak 2.732 rombongan belajar. Dalam Peraturan Menteri Pendidikan dan Kebudayaan No. 17 Tahun 2017 pasal 24 (c) tertulis bahwa jumlah rombongan belajar dalam satu kelas pada jenjang SMK berjumlah paling sedikit 15 peserta didik dan paling banyak 36 peserta didik, sehingga jika dihitung dengan jumlah penduduk jenjang pendidikan tersebut dibutuhkan 1.450 ruang kelas untuk memfasilitasi kegiatan pendidikan jenjang SMK di Kabupaten Kubu Raya. Jumlah rombongan belajar ini tidak sebanding dengan jumlah prasarana kelas yang ada di Kabupaten Kubu Raya sekarang yaitu 721 kelas.

Berdasarkan data BPS Kabupaten Kubu Raya Tahun 2018, persentase jumlah penduduk bekerja menurut lapangan kerja yaitu; pertanian, perkebunan, kehutanan, perburuan dan perikanan 45\%; pertambangan dan penggalian 0,25\%; industri 9,02\%; listrik, air dan gas 0,25\%; konstruksi, perdagangan, rumah makan dan jasa akomodasi $15,54 \%$; transportasi, pergudangan dan akomodasi 
3,65\%; lembaga keuangan, real estate, usaha persewaan dan jasa perusahaan 2,29\%; jasa kemasyarakatan $15,5 \%$.

Berdasarkan Peraturan Daerah Kabupaten Kubu Raya No. 16 Tahun 2009 tertulis misi Kabupaten Kubu Raya adalah meningkatkan perekonomian daerah yang berbasis ekonomi kerakyatan, agroindustri, teknologi, jasa, kemitraan, dan terwujudnya penerapan teknologi informasi dalam penyelenggaraan pemerintahan, pembangunan dan pelayanan publik, tersedianya sarana dan prasarana komunikasi dan informatika yang memadai dan berkualitas.

Berdasarkan Peraturan Direktorat Jenderal Pendidikan Dasar dan Menengah No. 06 Tahun 2018, program keahlian Teknik Komputer dan Informatika terdiri dari beberapa program keahlian yaitu Teknik Komputer dan Jaringan, Rekayasa Perangkat Lunak dan Multimedia, serta Sistem Informatika, Jaringan dan Aplikasi. Pembelajaran bertujuan untuk menghasilkan lulusan yang terampil di bidang perakitan, pemeliharaan komputer, pembuatan software aplikasi, serta media informasi dan komunikasi berbasis digital.

Apabila dibangun sekolah menengah kejuruan mengikuti standar dan mengikuti kompetensi keahlian pada program studi keahlian Teknik Komputer dan Informatika, maka terdapat 4 program keahlian yang sesuai dengan kebutuhan Kabupaten Kubu Raya yaitu Teknik Komputer dan Jaringan, Rekayasa Perangkat Lunak, Multimedia, serta Sistem Informatika, Jaringan dan Aplikasi. Sekolah tersebut dapat menampung maksimal 432 peserta didik yang terdiri dari tiga tingkatan kelas dengan total 12 rombongan belajar. Dari 53.998 jiwa jumlah penduduk di jenjang pendidikan SMK hanya dapat menutupi sekitar 0,6 \% dari jumlah penduduk jenjang pendidikan SMK di Kabupaten Kubu Raya.

Berdasarkan data Stasiun Pengamatan Bandar Udara Supadio Pontianak Tahun 2008 dalam Badan Perencanaan Pembangunan Daerah Kabupaten Kubu Raya (2009), Kabupaten Kubu Raya memiliki suhu dan kelembaban udara yang tinggi. Curah hujan rata-rata mengacu dari data Supadio Pontianak berkisar 3.136,4 milimeter per tahun atau 261.4 milimeter per bulan. Suhu udara di Kabupaten Kubu Raya tercatat paling rendah $22,5{ }^{\circ} \mathrm{C}$ dan suhu tertinggi $22,4{ }^{\circ} \mathrm{C}$. Secara geografi Kabupaten Kubu Raya termasuk dalam tipe iklim A yaitu iklim tropis.

Berdasarkan fakta dan data, dapat disimpulkan bahwa Kabupaten Kubu Raya membutuhkan bangunan SMK Komputer dan Informatika untuk memfasilitasi kebutuhan penduduk di jenjang pendidikan sekolah menengah kejuruan berdasarkan standar yang berlaku, pertimbangan kehidupan sosial, ekonomi, serta geografi di Kabupaten Kubu Raya. Pendekatan arsitektur yang sesuai untuk membangun Sekolah Menengah Kejuruan Teknik Komputer dan Informatika di Kabupaten Kubu Raya adalah arsitektur tropis yang mempertimbangkan penggunaan bahan bangunan dan pemanfaatan vegetasi untuk memberikan kenyamanan maksimal di ruangan belajar sekolah menengah kejuruan.

\section{Kajian Pustaka}

Berdasarkan Undang-Undang No. 20 Tahun 2003 satuan pendidikan adalah kelompok layanan pendidikan yang menyelenggarakan pendidikan jalur formal, nonformal, dan informal pada setiap jenjang dan jenis pendidikan. Sekolah menengah kejuruan atau pendidikan kejuruan merupakan satuan pendidikan formal yang bertugas menyelenggarakan pendidikan berbasiskan kejuruan pada jenjang menengah atas sebagai lanjutan dari SMP/MTs atau yang sederajat. SMK termasuk dalam pendidikan menengah. Pendidikan Menengah Kejuruan bertujuan untuk mempersiapkan peserta didik agar setelah lulus untuk mendapatkan pekerjaan. Berdasarkan Peraturan Menteri Pendidikan dan Kebudayaan Nomor 34 Tahun 2018 prinsip umum dalam proses pembelajaran SMK menganut pembelajaran sepanjang hayat dengan pendekatan ilmiah. Pembelajaran dengan prinsip umum menerapkan nilai teladan (ing ngarsa sung tualadha, membangun kemauan (ing madya mangun karsa), dan mengembangkan kreativitas peserta didik dalam proses pembelajaran (tut wuri handayani).

Menurut Djojonegoro (1999), tujuan sekolah menengah kejuruan yaitu mempersiapkan, memilih dan menempatkan calon tenaga kerja sesuai tanda-tanda pasar kerja. Pendidikan kejuruan tidak dapat 
dipisahkan dari permasalahan dunia kerja karena sekolah menengah kejuruan berhubungan langsung dengan bidang ketenagakerjaan. Evans (1978) mengartikan pendidikan kejuruan merupakan bagian dari sistem pendidikan yang mempersiapkan seseorang bekerja pada suatu kelompok pekerjaan atau satu bidang pekerjaan. Pendidikan kejuruan bertujuan agar kebutuhan tenaga kerja di masyarakat dapat terpenuhi, memberikan pilihan pada setiap masyarakat dan mendorong masyarakat agar memiliki motivasi untuk terus belajar.

Berdasarkan Peraturan Menteri Pendidikan Nasional Republik Indonesia Nomor 40 Tahun 2008 tentang standar sarana dan prasarana untuk SMK, terdapat pertimbangan satuan pendidikan untuk maksimum jumlah rombongan belajar yang dapat di tampung di sekolah menengah kejuruan. Sekolah menengah kejuruan wajib memiliki sarana dan prasarana yang dapat mewadahi minimum 3 rombongan belajar. Maksimum suatu sekolah menengah kejuruan dapat mewadahi 48 rombongan belajar. Sekolah menengah kejuruan sekurang-kurangnya harus memiliki fasilitas prasarana yang telah dikelompokkan dalam ruang pembelajaran umum, ruang penunjang, dan ruang pembelajaran khusus.

Menurut Haag dan Keen (1996), bahwa teknologi informasi/informatika merupakan "Seperangkat alat yang dapat membantu manusia dalam melakukan dan menyelesaikan tugas-tugas yang berkaitan dengan pemrosesan informasi dengan menggunakan teknologi komputer". Berdasarkan keputusan Direktur Jenderal Manajemen Pendidikan Dasar dan Menengah No. 251 Tahun 2008 spektrum keahlian pendidikan menengah kejuruan memuat bidang studi keahlian, program studi keahlian dan kompetensi keahlian. Berdasarkan spektrum 2008 program keahlian Teknik Komputer dan Jaringan terdiri dari Teknik Komputer dan Jaringan, Rekayasa Perangkat Lunak, Multimedia, serta Sistem Informatika, Jaringan dan Aplikasi. Pembelajaran pada program keahlian Teknik Komputer dan Informatika bertujuan untuk menghasilkan lulusan yang terampil di bidang perakitan, pemeliharaan komputer, pembuatan software aplikasi, serta media informasi dan komunikasi berbasis digital.

Menurut Satwiko (2009), keadaan iklim di Indonesia yang terbilang tropis lembab memerlukan beberapa syarat khusus untuk merancang bangunan, mengingat ada beberapa faktor-faktor spesifik yang hanya dapat dijumpai pada kondisi iklim tersebut. Berapa faktor yang dapat mempengaruhi kenyamanan bangunan di iklim tropis lembab yaitu ventilasi, pencahayaan dan akustika. Batas kenyamanan manusia untuk daerah Khatulistiwa adalah $19^{\circ} \mathrm{C}$ TE (batas bawah) $-26^{\circ} \mathrm{C}$ TE (batas atas). Pada temperatur $26^{\circ} \mathrm{C}$ TE umumnya manusia sudah mulai berkeringat. Menurut Lippsmeir (1997), daya tahan dan kemampuan kerja manusia mulai menurun pada temperatur $26^{\circ} \mathrm{C} \mathrm{TE}-30^{\circ} \mathrm{C}$ TE. Kondisi lingkungan tidak nyaman pada suhu $33,5^{\circ} \mathrm{C}$ TE $-35,5^{\circ} \mathrm{C}$ TE, dan pada suhu $35^{\circ} \mathrm{C} \mathrm{TE}-$ $36^{\circ} \mathrm{C}$ TE kondisi lingkungan tidak dapat ditolerir lagi. Karyono (2016) menyatakan, arsitektur tropis merupakan rancangan arsitektur yang mengarah pada pemecahan masalah yang ada di daerah beriklim tropis. Iklim tropis lembab memiliki karakteristik kelembaban udara relatif tinggi diatas 90\%, temperatur udara antara 18 OC hingga 35 OC, intensitas radiasi tinggi, dan intensitas hujan tinggi yang mencapai angka $3000 \mathrm{~mm} / \mathrm{tahun}$.

\section{Metode}

Perancangan Sekolah Menengah Kejuruan Teknik Komputer dan Informatika ini menggunakan metode yang terdiri dari studi literatur, survei dan studi preseden komparatif (Jones, 1980). Metode ini mengedepankan rasionalitas dalam pemecahan masalah perancangan. Metode perancangan seperti ini berfungsi untuk memecahkan masalah yang terdiri dari gagasan, informasi dan analisis. Setiap tahapan terdiri dari beberapa bagian yang akan dianalisis kemudian dikelola sehingga mendapatkan kesimpulan perancangan. Data perancangan yang dibutuhkan adalah data yang terkait informasi perancangan Sekolah Menengah Kejuruan Teknik Komputer dan Informatika yang sesuai untuk wilayah Kubu Raya. 


\section{Hasil dan Pembahasan}

Lokasi Sekolah Menengah Kejuruan Teknik Komputer dan Informatika terletak di jalan Arteri Supadio, Kecamatan Sungai Raya, Kabupaten Kubu Raya. Luas lahan perancangan adalah $20.061 \mathrm{~m}^{2}$. Batas lahan bagian Utara merupakan Jalan Parit Bugis, sisi Selatan merupakan lahan kosong, sisi Barat merupakan Jalan Arteri Supadio dan sisi Timur merupakan perumahan warga. Berdasarkan Peraturan Daerah Kabupaten Kubu Raya No. 16 Tahun 2009, Jalan Arteri Supadio merupakan jalan lokal primer dengan lebar 7 meter pada setiap ruas jalur. Keofisien Dasar Bangunan (KDB) sebesar 60\% dan Koefisien Lantai Bangunan (KLB) sebesar 2,4. Lahan yang digunakan untuk perancangan merupakan kawasan peruntukan pendidikan. Pertimbangan lokasi berpatokan pada pedoman penentuan standar pelayanan minimal bidang penataan ruang, perumahan dan permukiman dan pekerjaan umum Nomor 534 Tahun 2001 yang terdiri dari lahan yang bersih, mudah dicapai, tidak bising, jauh dari sumber bau sampah dan pencemaran lainnya.

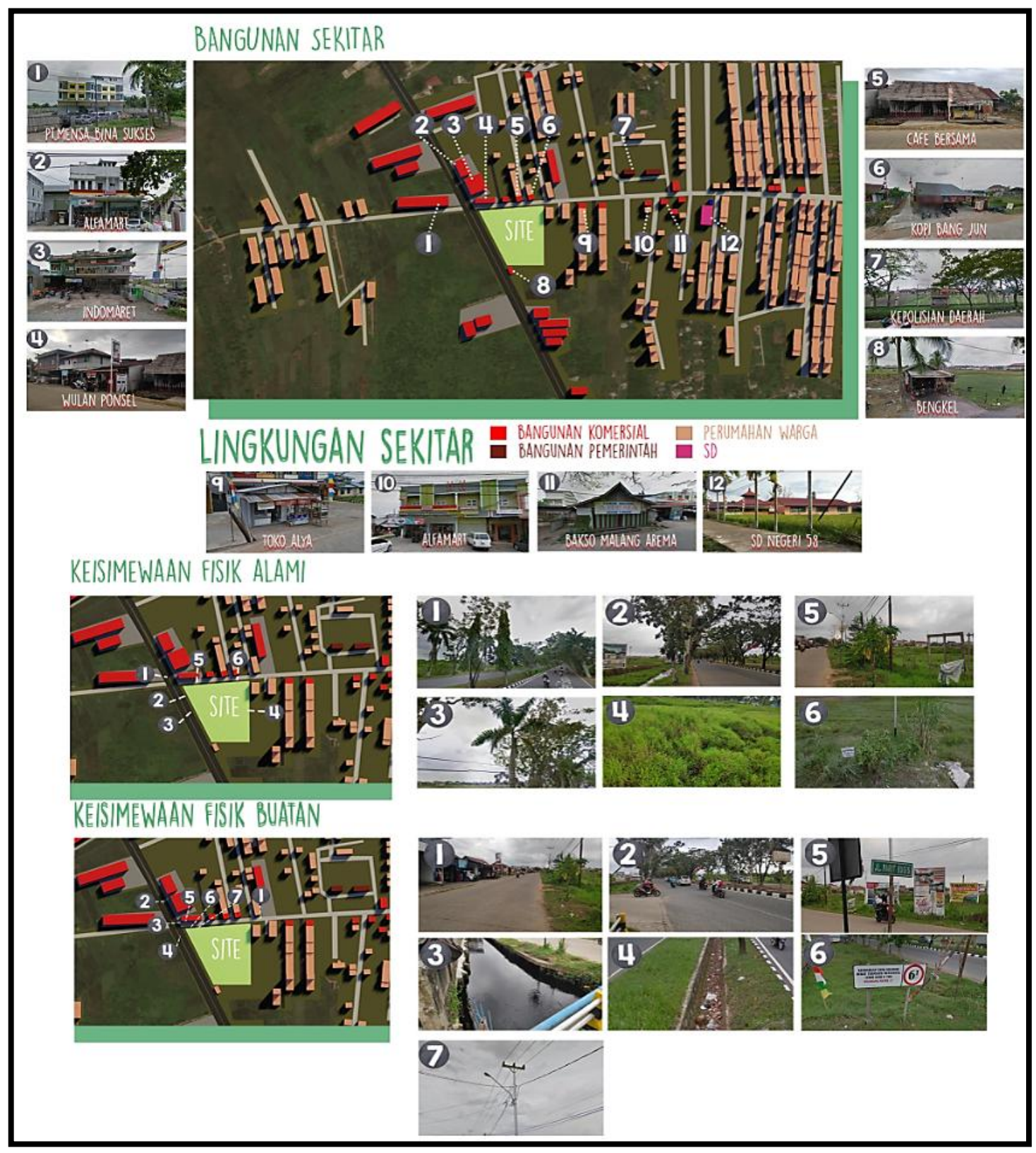

Gambar 1. Lokasi Perancangan

Sumber: Penulis, 2020 


\section{Landasan Konseptual}

Perancangan Sekolah Menengah Kejuruan Teknik Komputer dan Informatika di Kubu Raya mengacu pada pemahaman pendekatan arsitektur tropis berbasis teknologi utilitas bangunan dan material bangunan. Sistem otomatisasi pada jaringan utilitas terintegrasi dengan internet. Penerapan energi terbarukan seperti panel surya transparan yang diaplikasikan pada fasad bangunan untuk memenuhi sumber listrik bangunan serta digunakan sebagai penghambat sinar matahari masuk ke dalam ruangan.

Filosofi transformasi bentuk Sekolah Menengah Kejuruan Teknik Komputer dan Informatika di Kubu Raya menggunakan bentukan Printed Circuit Board yang dianalogkan dengan bentuk dan pola menekuk pada jalur konduktor yang menghubungkan dari satu komponen ke komponen lainnya. Bentukan menekuk pada bangunan memberikan akses ke setiap ruangan dan menyesuaikan bentukan lahan jajar genjang sehingga lebih efektif.

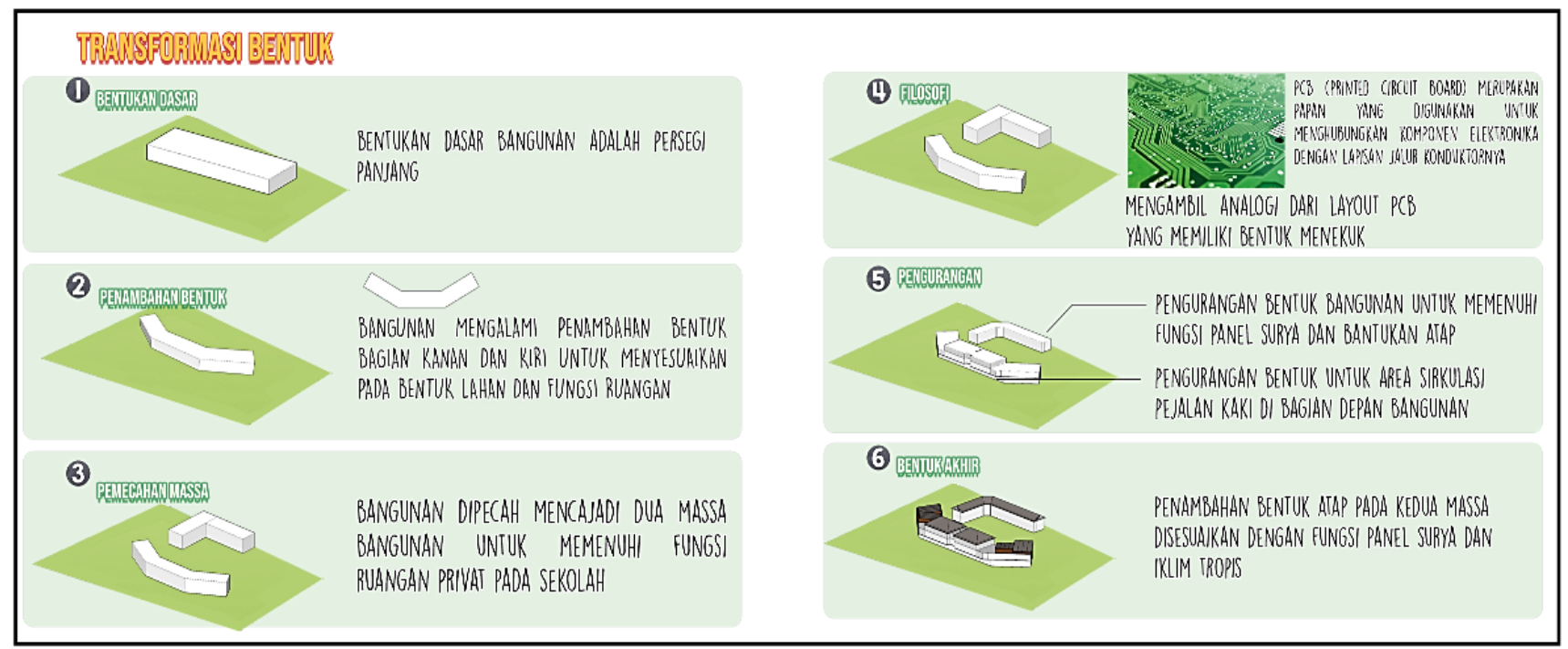

Gambar 2. Gubahan Massa

Sumber: Penulis, 2020

Menurut Pratomo (1995), Printed Circuit Board merupakan alat yang digunakan untuk menghubungkan komponen elektronik pada komputer dengan jalur konduktornya. Konsepsi tersebut kemudian dijadikan inspirasi perancangan perancangan secara analog gubahan bentuk Sekolah Menengah Kejuruan Teknik Komputer dan Informatika di Kabupaten Kubu Raya.

Konsep gubahan bentuk Sekolah Menengah Kejuruan Teknik Komputer dan Informatika di Kubu Raya melalui beberapa tahapan untuk menghasilkan bentukan yang telah dibuat sekarang. Bentukan dasar bangunan menggunakan bentukan persegi panjang yang dipecah menjadi dua massa bangunan. Bangunan menggunakan analogi dari Printed Circuit Board. Bangunan diselimuti dengan dua jenis secondary skin dengan pola persegi dan bentuk segitiga pada panel surya di depan bangunan utama.

Menurut Neufert (2003), atap bitumen tahan terhadap sinar matahari selama 60-70 tahun dan pemasangan minimal 2,5 $\geq$ derajat. Bentukan atap pada Sekolah Menengah Kejuruan Teknik Komputer dan informatika di Kubu Raya menggunakan atap kemiringan 30 derajat pada atap perisai dan pelana menyesuaikan dengan iklim tropis yang memiliki curah hujan sangat tinggi. Atap dengan kemiringan 8 derajat bertujuan memaksimalkan penyerapan sinar matahari pada panel surya. 


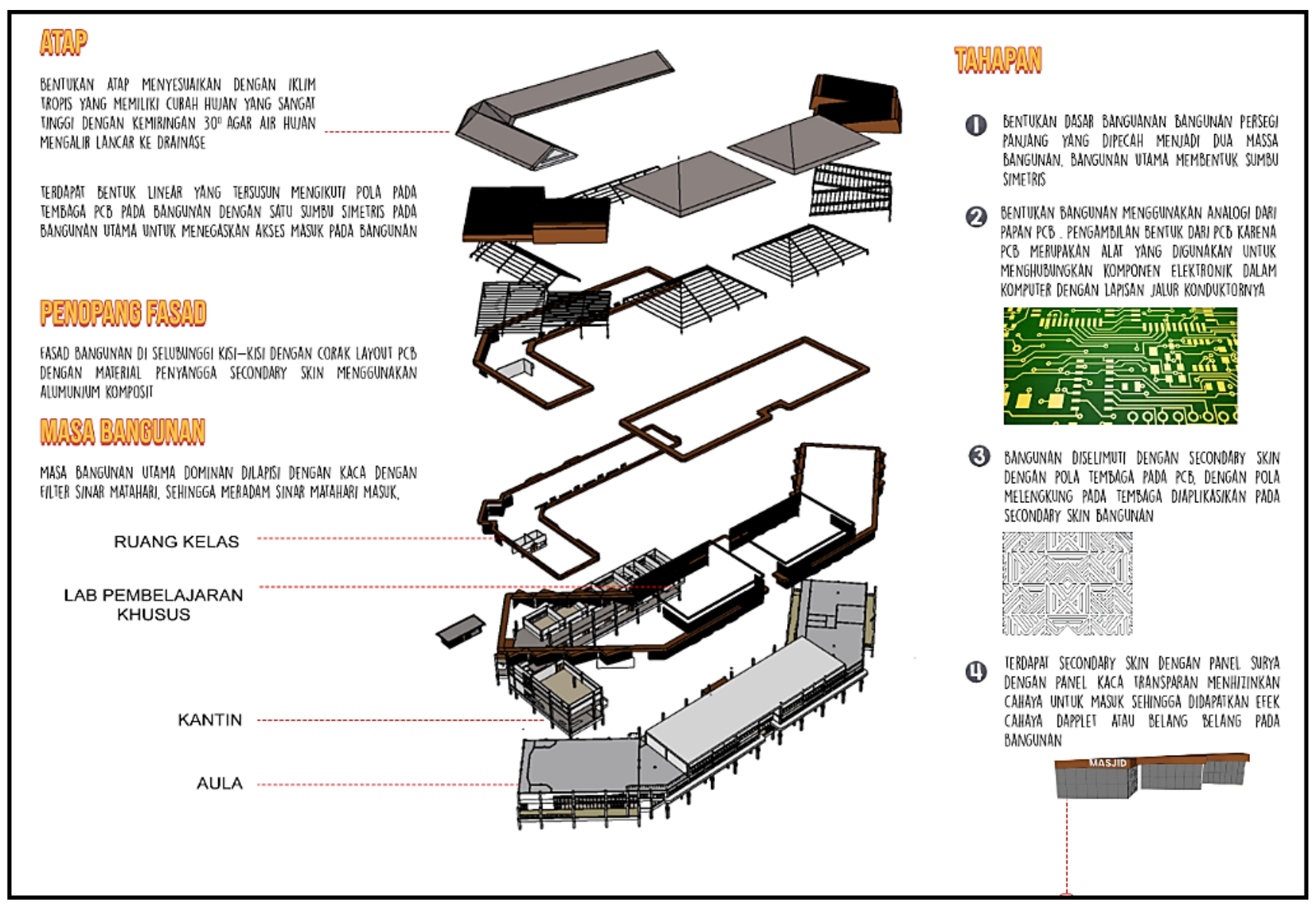

Gambar 3. Konsep Gubahan Bentuk

Sumber: Penulis, 2020

Sekolah Menengah Kejuruan Teknik Komputer dan Informatika terdiri dari 2 massa bangunan yang sama modulasinya. Modulasi bangunan berdasarkan kelipatan angka besaran ruang yang tipikal, yaitu 3 x 3 meter dan 9 x 9 meter. Bangunan terdiri dari sistem pondasi yang berbeda berdasarkan bentangan yang digunakan. Sistem struktur bawah masing-masing gedung menggunakan jenis pondasi pelat, dan mendapat tambahan penguatan dengan mini pile (Juwana, 2005). Jenis mini pile yang digunakan adalah beton bertulang. Ukuran pile cup pondasi dengan bentang 3 meter adalah menggunakan ukuran 1.2 x 0.8 meter. Untuk bentangan 9 meter menggunakan ukuran pile cup $1.2 \mathrm{x}$ 1.2 meter.

Sistem struktur atas bangunan menggunakan sistem rangka beton bertulang dan rangka baja sesuai dengan modul bangunan. Bentangan 3 meter menggunakan balok induk 0.15 x $0.3 \mathrm{~m}$, ukuran balok anak $0.13 \times 0.26 \mathrm{~m}$ dan lebar kolom beton yaitu $0.25 \times 0.25 \mathrm{~m}$. Untuk bentangan $9 \times 9 \mathrm{~m}$ ukuran balok induk yaitu $0.40 \times 0.75 \mathrm{~m}$, ukuran balok anak $0.25 \times 0.25 \mathrm{~m}$ dan lebar kolom beton yaitu $0.50 \times$ $0.50 \mathrm{~m}$. Dinding menggunakan bata ringan atau bata hebel, pelapis dinding menggunakan plester semen setebal $15 \mathrm{~cm}$ finish menggunakan cat berwarna serta untuk secondary skin menggunakan cutting laser plat baja.

Rangka atap bangunan menggunakan sistem truss karena cocok dan mudah diaplikasikan pada atap perisai dan pelana. Bahan rangka atap truss ini menggunakan baja struktural untuk bentangan sedang dan lebar. Struktur atap menggunakan dua jenis baja yaitu WF untuk kuda-kuda dan profil C untuk gording. Ukuran baja kuda-kuda atap yaitu $0.25 \times 0.12 \times 0.06 \times 0.09 \mathrm{~mm}$ dengan gording 0.12 x 0.65 x0.06 x $0.08 \mathrm{~mm}$. Penutup atap dalam perancangan gedung menggunakan material atap bitumen. Menurut Karyono (2016), penggunaan penutup atap bitumen dapat meredam panas matahari, memiliki nilai estetika, mampu meredam suara, ringan dan tahan air. Atap bitumen sangat cocok untuk 
semua cuaca, baik panas maupun dingin, dan hanya memerlukan rangka kuda-kuda dan gording dalam pemasangannya.

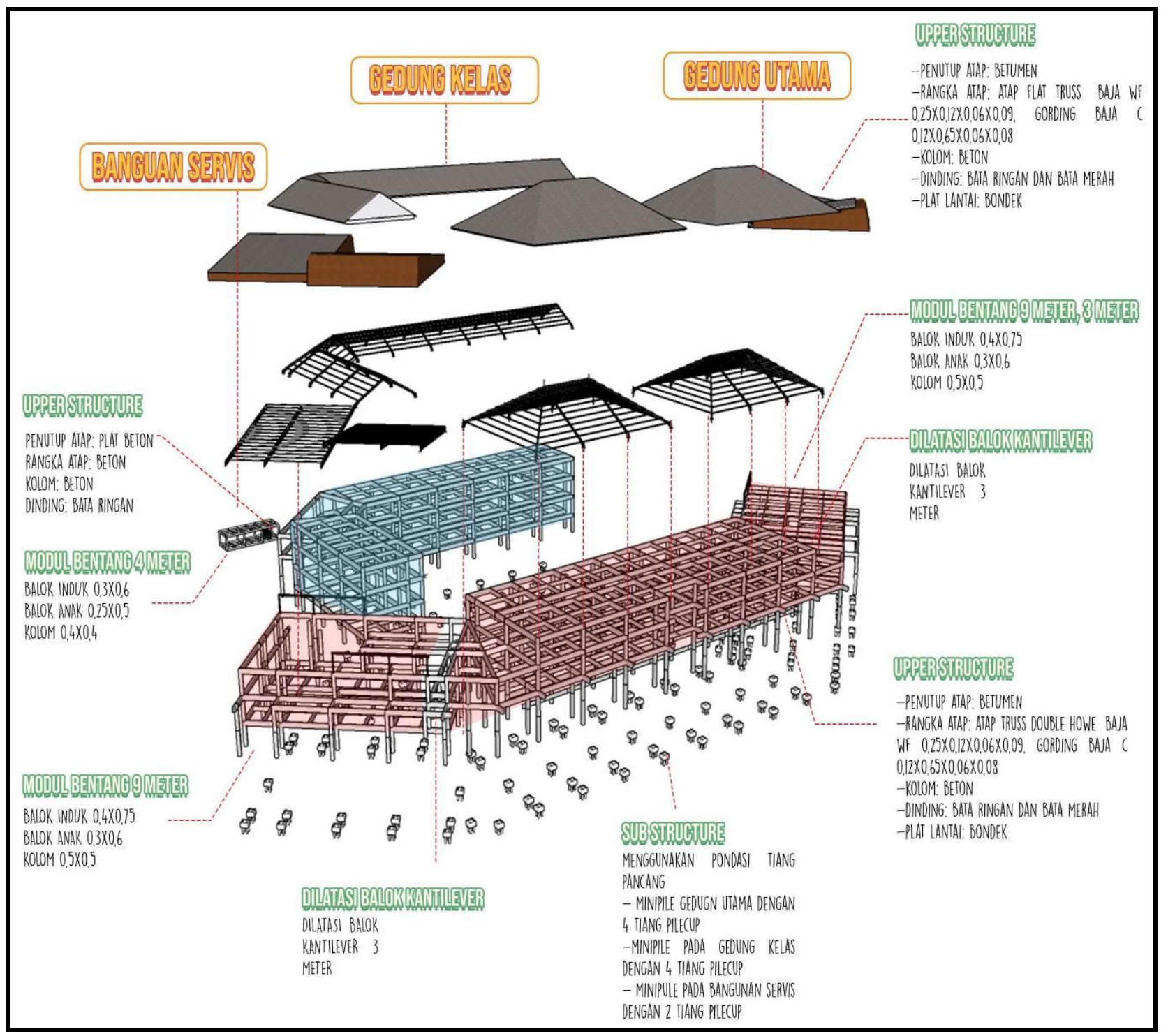

Gambar 4. Konsep Struktur

Sumber: Penulis, 2020

Rencana site plan Sekolah Menengah Kejuruan Teknik Komputer dan Informatika di Kubu Raya merupakan hasil analisis konsep perancangan. Gambar site plan menggambarkan keterhubungan tata ruang dalam bangunan dengan tata ruang luar bangunan. Rancangan ini meliputi bangunan dan area kawasan, berupa area parkir murid, parkir, area parkir guru, area parkir motor, parkir pengelola dan lapangan olahraga. Sekolah Menengah Kejuruan Teknik Komputer dan Informatika di Kubu Raya mempunyai tiga gedung yaitu gedung utama, gedung servis dan gedung kelas. Akses pada tapak bangunan terdapat jalan masuk utama di Jalan Arteri Supadio dan jalan masuk alternatif di Jalan Parit Bugis. Setiap jalan masuk kendaraan memiliki jalur keluar yang berdampingan dengan area jalan masuk bangunan. Area parkir murid dapat menampung 204 motor dan sepeda. Area parkir guru dan tamu dapat menampung sebanyak 74 mobil dan 117 motor. 


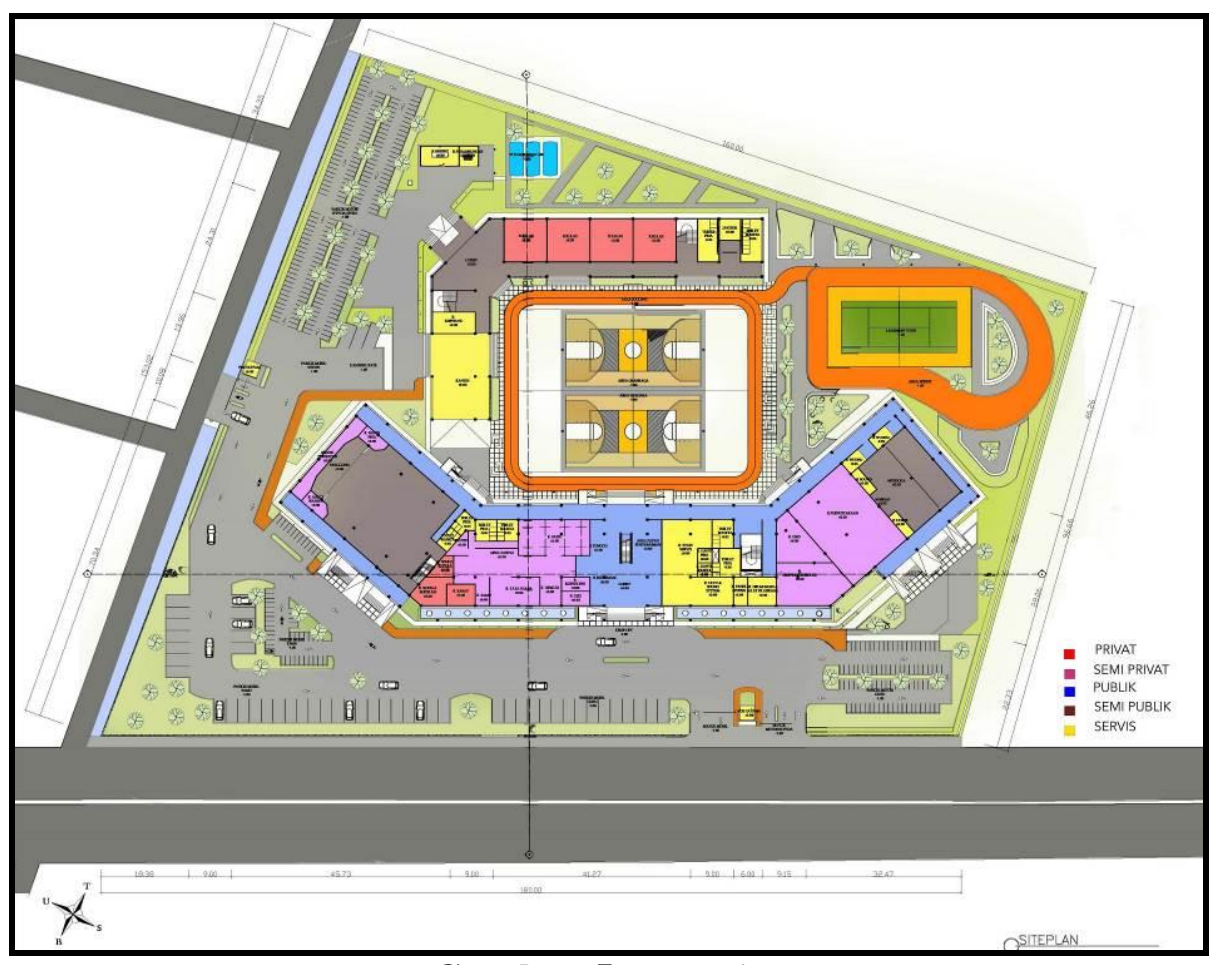

Gambar 5. Site Plan

Sumber: Penulis, 2020

Denah lantai dasar menjelaskan susunan tata ruang dalam bangunan lantai dasar. Denah lantai dasar gedung utama terdiri dari lobby, aula, ruang tata usaha, ruang wakil kepala, ruang kepala sekolah, ruang guru, ruang konseling, ruang uks, ruang servis, ruang ekstrakulikuler, ruang OSIS, ruang drum band, perpustakaan, musala, lavatory, gudang, ruang panel listrik dan cctv. Denah lantai dasar gedung kelas terdiri koperasi, gudang, ruang kelas dan toilet. Pada ruangan serbaguna dapat menampung maksimal 464 dan pada area musala dapat menampung maksimal 100 orang.

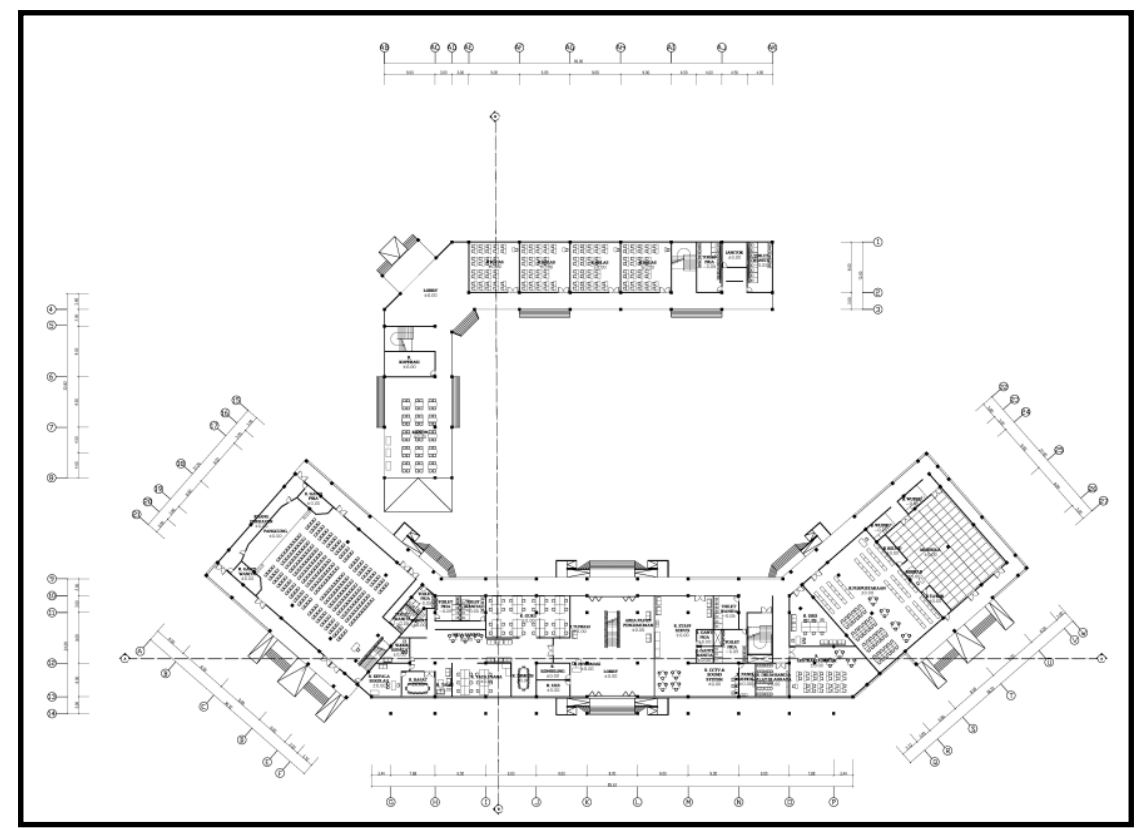

Gambar 6. Denah lantai dasar

Sumber: Penulis, 2020 
Denah lantai satu menggambarkan susunan tata ruang dalam bangunan lantai satu. Gambar denah lantai satu gedung utama terdiri dari ruang arsip, ruang infrastruktur, ruang perawatan perbaikan, laboratorium khusus rekayasa perangkat lunak, ruang seni budaya, ruang TIK, laboratorium khusus teknik komputer dan jaringan, laboratorium khusus, ruang perawatan perbaikan, ruang server, ruang praktik pengembangan aplikasi, ruang praktik instalasi jaringan, ruang perawatan perbaikan, area mekanik teknik elektro, ruang praktik pengembangan perangkat lunak, laboratorium multimedia, ruang menggambar dan suara. Lantai dasar gedung kelas terdiri kantin, gudang, ruang kelas dan toilet.

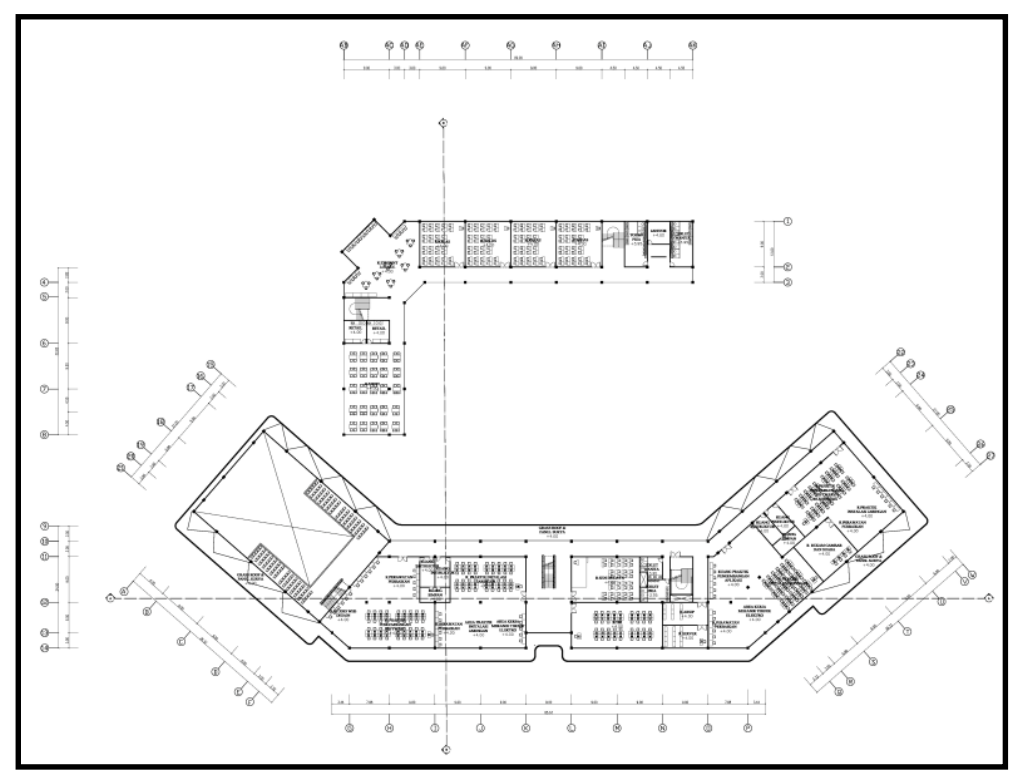

Gambar 7. Denah lantai satu

Sumber: Penulis, 2020

Denah lantai dua menggambarkan susunan tata ruang dalam bangunan lantai dua. Denah lantai dua gedung utama terdiri dari laboratorium kimia, laboratorium bahasa, ruang praktik gambar teknik, laboratorium sistem komputer, laboratorium fisika, laboratorium komputer, gudang dan toilet. Lantai dasar gedung kelas terdiri gudang, ruang kelas dan toilet.

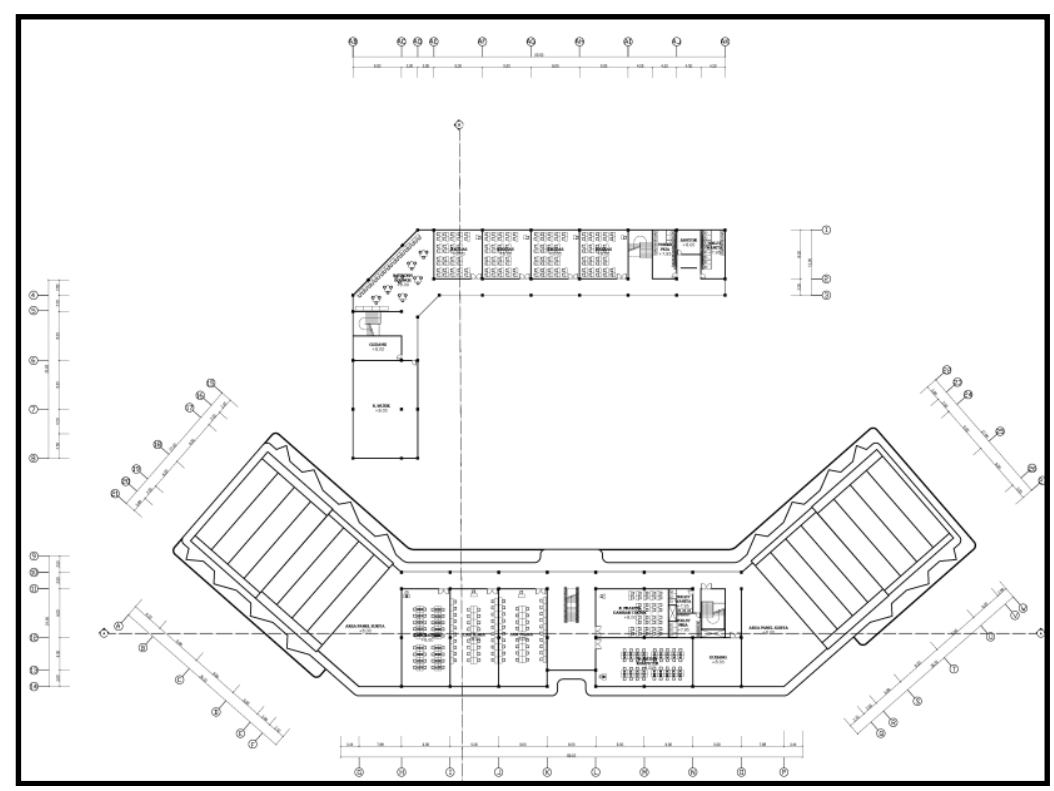

Gambar 8. Denah lantai dua

Sumber: Penulis, 2020 
Sekolah Menengah Kejuruan Teknik Komputer dan Informatika di Kubu Raya merupakan bangunan pendidikan dengan dua massa bangunan. Diantara dua massa tersebut terdapat lapangan olahraga dan lapangan upacara yang dapat digunakan sebagai sirkulasi penghubung antara setiap massa bangunan. Tampak depan dan belakang Sekolah Menengah Kejuruan Teknik Komputer dan Informatika di Kubu Raya merupakan bentuk respon tapak dengan orientasi utamanya yang menghadap ke arah jalan utama didominasi dengan secondary skin dengan gabungan panel surya. Bentuk corak secondary skin ini mengikuti pola menekuk pada Printed Circuit Board yang memiliki arti efektifitas. Bentuk yang ingin ditampilkan pada secondary skin ini adalah pola bentuk yang berbeda untuk menciptakan kesan dinamis pada bangunan, dimana pola secondary skin mengikuti bentukan bangunan utama yaitu berbentuk persegi panjang.

Tampak samping kiri dan kanan Sekolah Menengah Kejuruan Teknik Komputer dan Informatika di Kubu Raya menunjukan ketinggian dua masa bangunan yang memiliki jarak dan disatukan dengan lapangan yang terletak ditengah-tengah. Warna bangunan dominan putih yang menciptakan nuansa bersih. Pada atap bangunan gedung utama, struktur atap yang digunakan adalah atap flat truss dengan kemiringan 8 derajat yang dimanfaatkan untuk meletakkan panel surya sebagai penghemat sumber energi listrik pada bangunan.

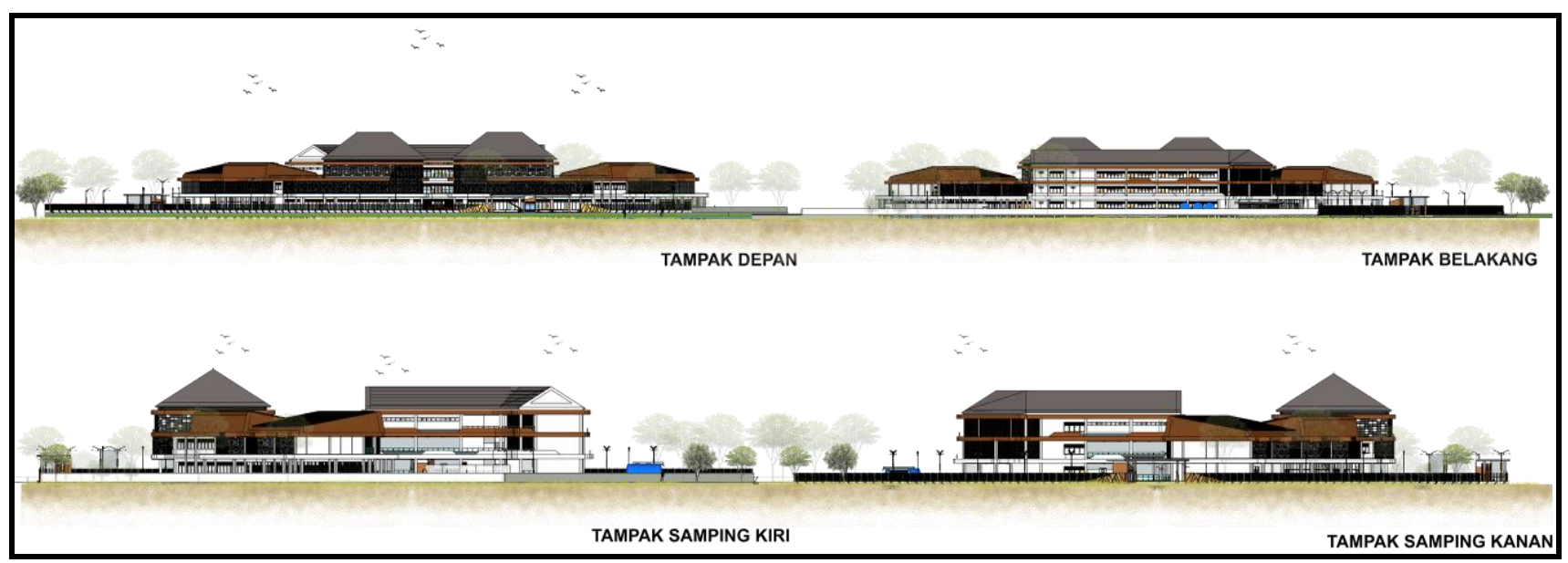

Gambar 9. Tampak

Sumber: Penulis, 2020

Sekolah Menengah Kejuruan Teknik Komputer dan Informatika di Kubu Raya merupakan kawasan pendidikan yang memiliki dua massa bangunan dengan satu tema yang sama, sehingga perancangan ini menggunakan dua macam potongan yaitu potongan A-A dan potongan $\mathrm{B}-\mathrm{B}$. Terdapat 4 jenis atap yang berbeda. Bagian tengah bangunan utama menggunakan atap perisai. Atap perisai pada bangunan sangat cocok untuk mengalirkan air hujan ke drainase bangunan. Pada bagian ruangan serbaguna menggunakan struktur atap portal bentang lebar dengan material baja jenis flat truss. Bagian bangunan kelas menggunakan atap pelana dengan rangka struktur atap howe truss.

Struktur atas pada bangunan Sekolah Menengah Kejuruan Teknik Komputer dan Informatika di Kubu Raya menggunakan sistem struktur rangka beton bertulang yang mengandalkan kolom dan balok sebagai penghantar beban bangunan. Pada potongan Sekolah Menengah Kejuruan Teknik Komputer dan Informatika di Kubu Raya terdapat tangga umum dan tangga darurat sebagai media transportasi pada bangunan. Terdapat tangga darurat pada bangunan utama sebagai jalur sirkulasi keselamatan pada saat kebakaran. Tangga darurat pada bangunan dipertimbangkan berdasarkan jarak terdekat pada setiap ruangan yang berada di Sekolah Menengah Kejuruan Teknik Komputer dan Informatika di Kubu Raya. 


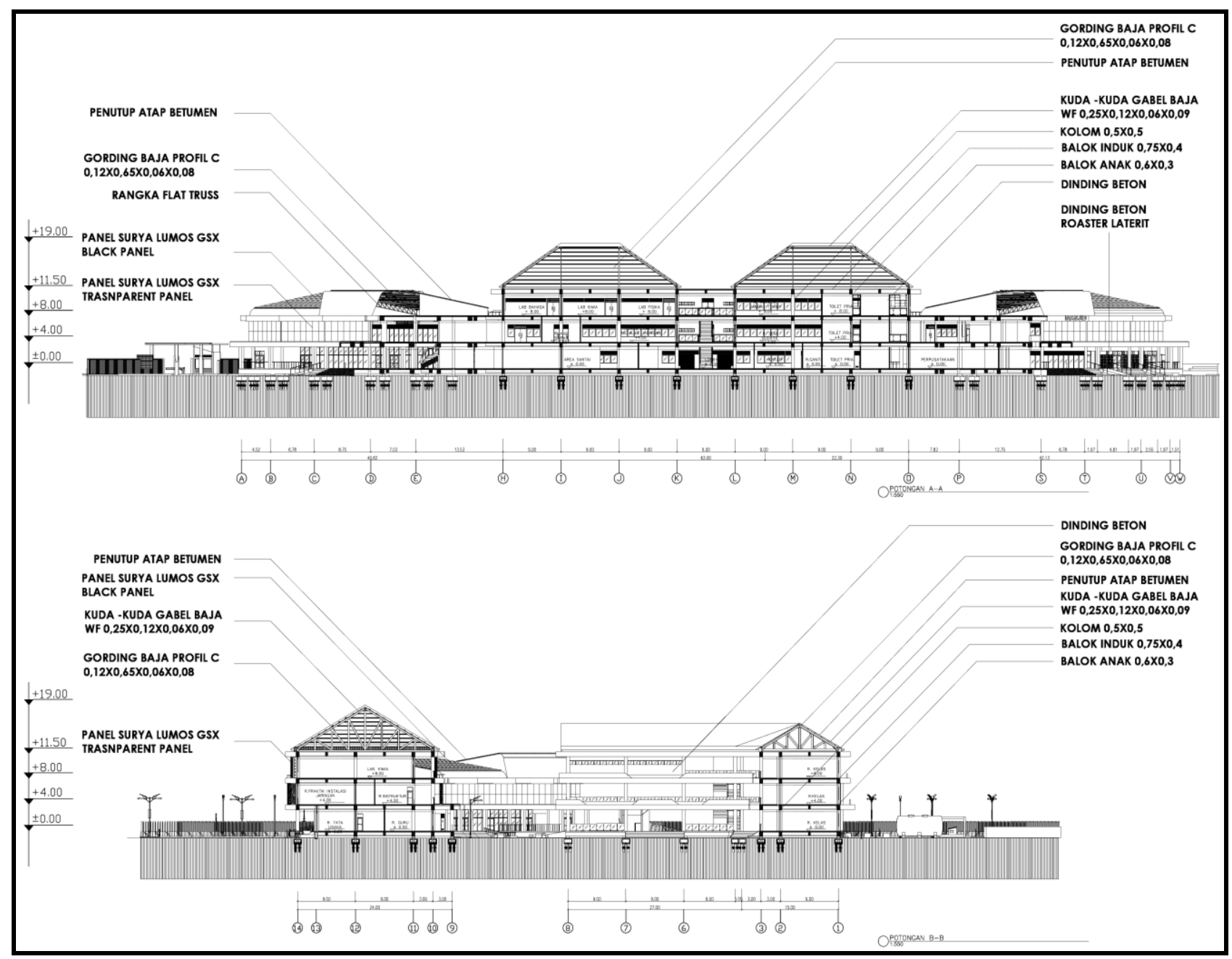

Gambar 10. Potongan

Sumber: Penulis, 2020

Sekolah Menengah Kejuruan Teknik Komputer dan Informatika di Kubu Raya merupakan bangunan pendidikan dengan pendekatan arsitektur tropis. Bangunan Sekolah Menengah Kejuruan Teknik Komputer dan Informatika memiliki dua massa bangunan yang menghadap langsung ke Jalan Arteri Supadio. Permainan material yang menyesuaikan iklim tropis disesuaikan dengan tema arsitektur tropis sehingga terlihat lebih modern. Sebagian dinding pada lantai dasar menggunakan material bata dan roster dengan material tanah mati, material ini bisa didapat di Kalimantan. Bagian fasad kebanyakan ditutupi dengan secondary skin dan kaca besar material baja ringan sehingga dapat memberikan kesan high tech pada bangunan. Pada bagian depan kawasan diberikan tanaman dan kolam untuk memberikan nuansa tropis dan sejuk pada bangunan Sekolah Menengah Kejuruan Teknik Komputer dan Informatika di Kubu Raya. Bagian tengah terdapat lapangan olahraga dan lapangan upacara lapangan olahraga terdiri dari lapangan voli, basket, tenis dan jogging track. Pada area belakang bangunan terdapat area servis seperti ruangan genset, tempat sampah dan penyimpanan air.

Sisi Barat kawasan terdapat area parkir yang dekat dengan jalur utama dan parkir motor diletakkan dekat dengan bangunan. Terdapat jalur pedestrian pada depan bangunan agar memudahkan pengguna untuk mengakses ke dalam bangunan. Pada area barat terdapat parkiran pengelola, pengunjung, dan siswa. Peletakan tempat parkir di bagian barat untuk memudahkan siswa dalam mengakses bangunan yang dekat dengan ruangan kelas. Akses parkiran pengelola berdekatan dengan kedua massa bangunan agar memudahkan pengangkatan barang ke dalam bangunan. Pada area parkir 
ditanami pepohonan peneduh untuk meneduhkan dan menjaga kendaraan dari paparan sinar matahari. Pada area parkir juga terdapat lampu taman dengan panel surya sebagai sumber tenaga pencahayaanya.

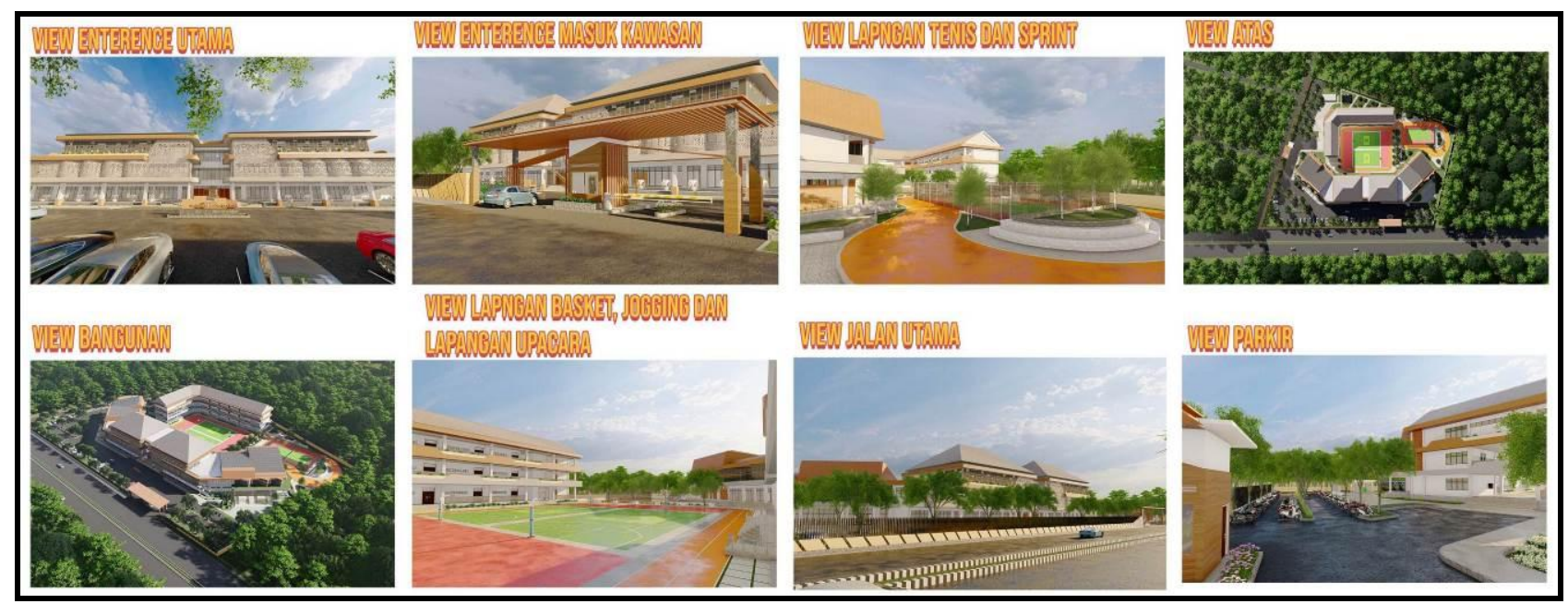

Gambar 11. Suasana Eksterior

Sumber: Penulis, 2020

Sekolah Menengah Kejuruan Teknik Komputer dan Informatika merupakan bangunan yang menerapkan pemahaman arsitektur tropis sehingga suasana ruang, material, warna, perabot, dinding, dan struktur bangunan memberikan kesan tropis dan modern. Pada area lobby sekolah menggunakan material dinding dengan cat putih dan dinding bata merah laterit yang bertujuan untuk memberikan suasana modern dan sejuk. Pada area lobby sekolah terdapat papan informasi, tempat duduk, tempat sampah, dan tanaman hias. Terdapat pintu masuk dan sirkulasi pengunjung yang besar pada area lobby bertujuan untuk memudahkan akses pengunjung dan memberikan sirkulasi udara yang baik pada ruangan.

Suasana ruang kelas, ruang guru, ruang tata usaha, ruang rapat dominasi warna putih ruangan terlihat bersih, rapi sehingga nyaman digunakan saat melakukan kegiatan belajar mengajar, dan berdiskusi. Pada area ruang musala banyak didominasi dengan material bata dan roster. Penggunaan roster dan bata berfungsi untuk mempermudah dan mempercepat sirkulasi angin keluar dan masuk pada area beribadah di dalam ruangan tidak gerah dan panas.

Suasana ruang serbaguna didominasi warna putih dan cream dengan railing material kaca memberikan kesan modern pada ruangan. Material dinding menggunakan bata hebel dengan penutup plaster dengan dominasi kaca untuk memaksimalkan pencahayaan alami pada ruangan. Cahaya pada ruangan serbaguna memiliki intensitas yang baik karena terdapat secondary skin panel surya dengan panel transparan yang memberikan efek cahaya luminasi pada ruangan. Perabotan yang terdapat pada ruangan serbaguna terdiri dari kursi yang dapat dipindahkan, panggung untuk acara sekolah atau luar sekolah, toilet pada bagian belakang ruang serbaguna untuk memudahkan pengunjung.

Suasana ruang guru, ruang tata usaha, ruang diskusi, dan ruang rapat diberikan warna soft pada dinding dan lantai ruangan. Bukaan yang besar dan peletakan kolam pada depan ruangan memberikan akses udara masuk dan kesan sejuk pada ruangan agar tidak panas dan lembab. Perabotan yang terdapat pada ruangan ini adalah kursi kerja, kursi rapat, meja kerja, meja rapat, papan tulis, alat kerja tata usaha dan guru, dan alat print. Dinding pada area kerja hanya diberikan sekat sedangkan ruangan rapat tertutup untuk memberikan suasana yang privat yang nyaman ketika kegiatan rapat guru. 


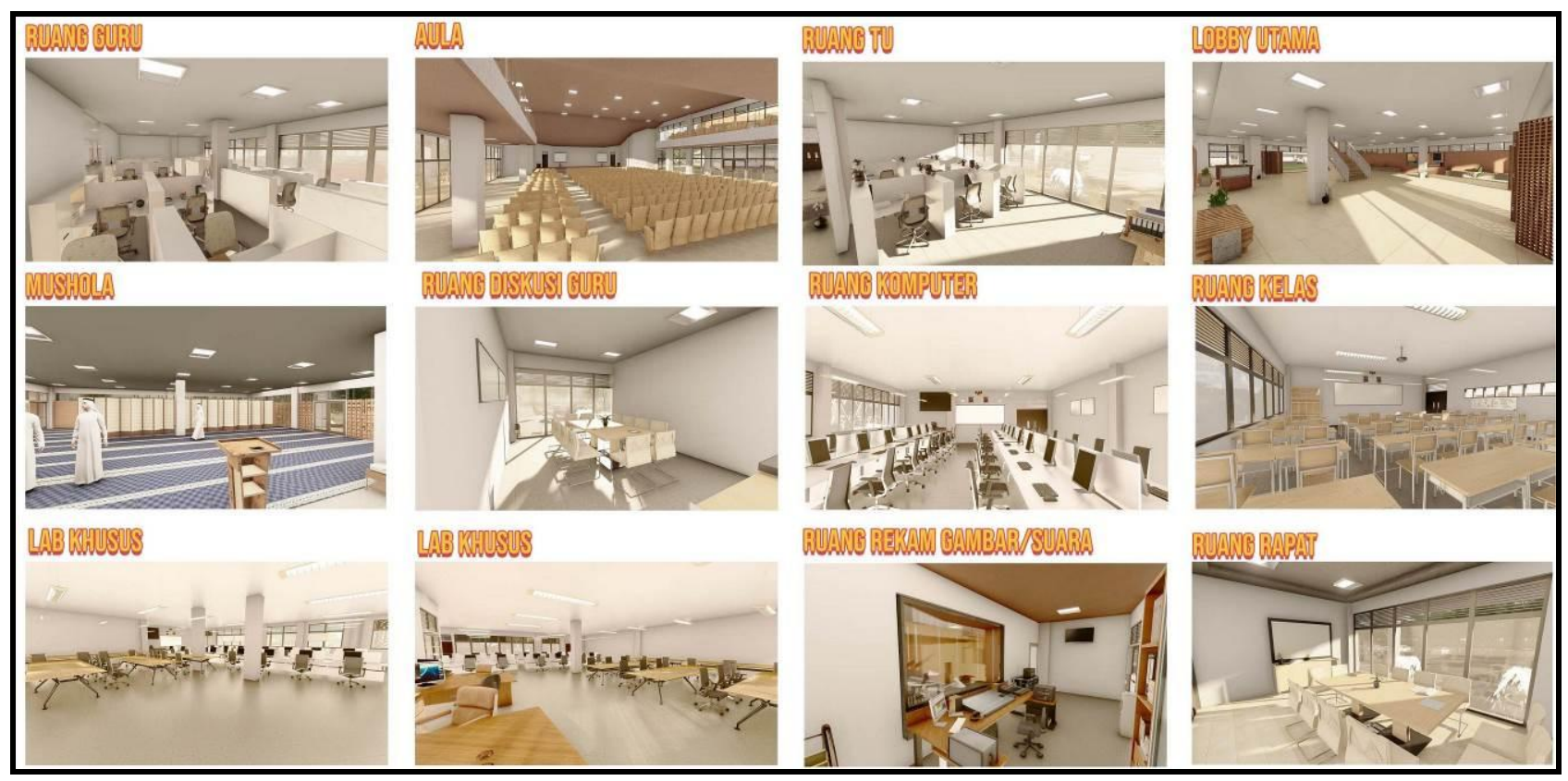

Gambar 12. Suasana Interior

Sumber: Penulis, 2020

\section{Kesimpulan}

Perancangan sekolah Menengah Kejuruan Teknik Komputer dan Informatika di Kubu Raya merupakan solusi untuk menciptakan sumber daya manusia yang mumpuni untuk mengembangkan industri teknologi. Perancangan Sekolah Menengah Kejuruan Teknik Komputer dan Informatika di Kubu Raya menerapkan pendekatan arsitektur tropis dengan mempertimbangkan prinsip kenyamanan spasial pada bangunan terkait aspek ukuran tubuh pengguna bangunan, aspek ruang gerak manusia berdasarkan aktivitas manusia di dalamnya, kenyamanan audial, kenyamanan visual dan kenyamanan termal pada bangunan. Penerapan energi terbarukan seperti pembangkit listrik tenaga surya dan penerapan material lokal menciptakan suasana arsitektur tropis pada bangunan, seperti dinding dan roaster bata laterit untuk menyerap kelembaban udara menyesuaikan geografis Kabupaten Kubu Raya.

\section{Ucapan Terima Kasih}

Ucapan syukur kepada Tuhan Yang Maha Esa karena penulis diberikan kemudahan dalam mengerjakan dan menyelesaikan Proyek Tugas Akhir ini. Terima kasih kepada orang tua yang selalu memberikan semangat, dukungan dan doa. Kepada para dosen pembimbing dan penguji Proyek Tugas Akhir atas bimbingan, kritik dan saran untuk penulis. Ungkapan terima kasih Kepada seluruh teman, sahabat dan keluarga yang telah banyak memberikan doa dan dukungan dalam pengerjaan Proyek Tugas Akhir ini.

\section{Daftar Acuan}

Badan Perencanaan Pembangunan Daerah Kabupaten Kubu Raya. (2009). Peraturan Daerah Kabupaten Kubu Raya Nomor 16 Tahun 2009 Tentang Rencana Pembangunan Jangka Panjang Kabupaten Kubu Raya Tahun 2009-2029. Kubu Raya: Badan Perencanaan Pembangunan Daerah Kabupaten Kubu Raya

Badan Pusat Statistik Kabupaten Kubu Raya. (2018). Kabupaten Kubu Raya Dalam Angka 2018. Kubu Raya: Badan Pusat Statistik Kabupaten Kubu Raya

Direktorat Jenderal Pendidikan Dasar dan Menengah. (2018). Peraturan Jenderal Pendidikan Dasar dan Menengah Nomor 6 Tahun 2018 Tentang Spektrum Keahlian Sekolah Menengah Kejuruan (SMK)/Madrasah Aliyah Kejuruan (MAK). Jakarta: Kementerian Pendidikan dan Kebudayaan Republik Indonesia

Direktorat Jenderal Pendidikan Dasar dan Menengah. (2008). Peraturan Jenderal Pendidikan Dasar dan Menengah Nomor 251 Tahun 2008 Tentang Spektrum Keahlian Sekolah Menengah Kejuruan. Jakarta: Kementerian Pendidikan dan Kebudayaan Republik Indonesia 
Djojonegoro, W. (1999). Pengembangan Sumberdaya Manusia Sekolah Menengah Kejuruan. Jakarta: Balai Pustaka Evans, R. N. (1978). Foundation of Vocational Education. Ohio: Charles E. Merrill Publishing Company

Haag, S., \& Peter, K. (1996). Information Technology: Tomorrow's Advantage Today. Hammond: Mcgraw-Hill College Jones, J. (1980). Design Methods: Seeds of Human Future. New York: John Wiley \& Sons

Juwana, J. S. (2018). Panduan Sistem Bangunan Tinggi. Jakarta: Erlangga

Karyono, T. H. (2016). Arsitektur Tropis Bentuk, Teknologi, Kenyamanan, dan Penggunaan Energi. Jakarta: Erlangga

Kementerian Pendidikan Nasional Republik Indonesia. (2008). Peraturan Menteri Pendidikan Nasional Republik Indonesia Nomor 40 Tahun 2008 Tentang Standar Sarana dan Prasarana untuk Sekolah Menengah Kejuruan/Madrasah Aliyah Kejuruan (SMK/MAK). Jakarta: Kementerian Pendidikan dan Kebudayaan Republik Indonesia

Kementerian Pendidikan dan Kebudayaan Republik Indonesia. (2017). Peraturan Menteri Pendidikan Nasional Republik Indonesia Nomor 17 Tahun 2017 Tentang Peserta Didik Baru Pada Taman Kanak-Kanak, Sekolah Menengah Atas, Sekolah Menengah Kejuruan atau Bentuk Lain yang Sederajat. Jakarta: Kementerian Pendidikan dan Kebudayaan Republik Indonesia

Kementerian Pendidikan dan Kebudayaan Republik Indonesia. (2018). Peraturan Menteri Pendidikan Nasional Republik Indonesia Nomor 34 Tahun 2018 Tentang Standar Nasional Pendidikan Sekolah Menengah Kejuruan/Madrasah Aliyah Kejuruan. Jakarta: Kementerian Pendidikan dan Kebudayaan Republik Indonesia

Kementerian Pemukiman dan Prasarana Wilayah. (2001). Peraturan Menteri Pemukiman dan Prasarana Wilayah Nomor 534 Tahun 2001 Tentang Pedoman Penentuan Standar Pelayanan Minimal Bidang Penataan Ruang, Perumahan dan Permukiman dan Pekerjaan Umum. Jakarta: Kementerian Permukiman dan Prasarana Wilayah

Lippsmeir, G, E. (1997). Bangunan Tropis. Jakarta: Erlangga

Neufert, E. (2003). Data Arsitek Jilid 1. Jakarta: Erlangga

Pratomo, P. (1995). Tuntunan Praktis Perancangan dan Pembuatan PCB. Jakarta: Alex Media Komputindo

Satwiko, P. (2009). Fisika Bangunan. Yogyakarta: ANDI Yogyakarta

Sekretariat Negara Republik Indonesia. (2003). Undang-undang Nomor 20 Tahun 2003 Tentang Sistem Pendidikan Nasional. Jakarta: Sekretariat Negara Republik Indonesia 